\title{
Pendampingan Pembuatan AD/ART Dalam Rangka Meningkatkan Mekanisme Kerja Koperasi Pada Koperasi Wanita Swatika Desa Miagan Kecamatan Mojoagung Kabupaten Jombang
}

\author{
Retno Catur Kusuma Dewi \\ STIE PGRI Dewantara Jombang \\ Korespondensi: retno.dewantara@gmail.com
}

Diserahkan: 1 Desember 2018, Direvisi: 13 Desember 2018 Diterbitkan: 22 Desember 2018

\begin{abstract}
abstrak
Koperasi Wanita Swatika merupakan organisasi usaha ekonomi rakyat yang termasuk dalam koperasi jenis simpan pinjam berdasarkan pada tanggal 18 Maret 2010 dengan Nomor Ijin 518.1/239/BH/XVI.8/415.35/2010, dimana koperasi Swatika ini berbeda dengan koperasi jenis simpan pinjam yang lainnya. Sebab, tidak adanya sebuah jaminan dalam kegiatan usaha koperasi ini menyebabkan tidak adanya kontrol dan pengawasan dalam organisasi internal koperasi ini. Selain itu timbulnya kesimpangsiuran dalam pelaksanaan organisasi koperasi oleh alat-alat perlengkapan koperasi itu sendiri. Minimnya pemahaman tentang koperasi membuat Koperasi Swatika ini belum mempunyai AD/ART sebagai dasar penyusunan peraturan-peraturan yang terkait dengan kegiatan koperasi baik internal maupun eksternal. Maka dengan tujuan kegiatan pengabdian ini adalah memberikan pendampingan pembuatan AD/ART Koperasi Wanita Swatika. Manfaat kegiatan pengabdian masyarakat ini adalah memberikan pemahaman kepada anggota koperasi dan pengurusnya untuk membuat AD/ART dalam rangka meningkatkan efektifitas dan mekanisme kerja koperasi wanita (Kopwan) Swatika dengan tetap memperhatikan ketentuan yang ada di dalam Undang-Undang No 25 Tahun 1992 tentang Perkoperasian.
\end{abstract}

Kata kunci: Koperasi Swatika, AD/ART, Desa Miagan

\section{abstract}

Wanita Swatika Cooperative is a people's economic business organization which is included in a savings and loan cooperative based on March 18, 2010 with License Number $518.1 / 239$

/ BH / XVI.8 / 415.35 / 2010, where the Swatika cooperative is different from other savings and loan cooperatives. Because, the absence of a guarantee in the cooperative business activities led to the absence of control and supervision in the cooperative's internal organization. In addition, the emergence of confusion in the implementation of cooperative organizations by the cooperative equipment itself. The lack of understanding of cooperatives has made the Swatika Cooperative not yet have AD / ART as a basis for drafting regulations related to cooperative activities both internally and externally. So with the aim of this service activity is to provide assistance in the creation of the Women Swatika Cooperative AD / ART. The benefit of this community service activity is to provide understanding to members of the cooperative and their management to make statutes /ART in order to increase the effectiveness and working mechanism of the Swatik women's cooperative (Kopwan) while taking into account the provisions in Law No. 25 of 1992 concerning Cooperatives.

Keywords: Swatika Cooperative, AD / ART, Miagan Village

\section{A. PENDAHULUAN}

Koperasi merupakan salahsatu penggerak roda perekonomian baik di lingkungan pedesaan maupun perkotaan. Undang-Undang No 25 tahun 1992 Tentang Perkoperasian telah mengakomodasi segala aktifitas dan mekanisme tentang Perkoperasian. Diterbitkannya Undang-undang No 25 tahun 1992 tentang Perkoperasian ini semakin memberikan dampak positif bagi perkembangan koperasi. Perkembangan koperasi semakin berkembang dengan cepat karena adanya kemudahan 
dalam pendirian koperasi.

Anggaran Dasar atau anggaran Rumah Tangga yang selanjutnya disebut AD/ART adalah salah satu syarat utama yang harus ada setelah koperasi itu dibentuk atau didirikan sebagaimana yang tercantum di dalam pasal 17 ayat 1 Undang-Undang No 25 Tahun 1992 Tentang Perkoperasian yaitu "Pembentukan koperasi dilakukan dengan akta pendirian yang memuat anggaran dasar". Berdasarkan pasal 18 Undangundang No 25 Tahun 1992 Tentang Perkoperasian, anggaran dasar koperasi memuat sekurang-kurangnya:

a. Daftar nama pendiri

b. Nama dan tempat kedudukan koperasi

c. Maksud dan tujuan serta bidang usaha koperasi

d. Ketentuan mengenai keanggotaan

e. Ketentuan mengenai rapat anggota

f. Ketentuan mengenai pengelolaan

g. Ketentuan mengenai permodalan

h. Ketentuan mengenai jangka waktu berdirinya koperasi

i. Ketentuan mengenai pembagian sisa hasil usaha koperasi

j. Ketentuan mengenai sanksi

Kedudukan AD/ART tidak hanya sebagai aturan formal di dalam pengesahan badan hukum bagi koperasi. Adapun tujuan penting dengan adanya AD/ART sebagai berikut:

a. Sasaran dari tujuan pembentukan koperasi dapat mudah dicapai;

b. Pelaksanaan dari organisasi koperasi dapat terhindar dari ketidakpastian atau kesimpangsiuran;

c. Dapat melaksanakan kegiatan-kegiatan organisasi usaha ekonomi rakyat;

d. Sebagai pedoman dalam dasar penyusunan aturan-aturan yang berlaku koperasi yang bersangkutan.

Beberapa masalah yang dihadapi oleh Koperasi Wanita atau Kopwan Swatika yaitu salahsatunya masih rendahnya pemahaman anggota akan kegunaan dan fungsi AD/ART, sehingga membuat mekanisme dan kerja koperasi menjadi terhambat. Oleh karena itu, perlu banyak pihak untuk membantu mendampingi akan peran pentingnya AD/ART dalam mekanisme kerja koperasi. Salah satunya dengan memberikan pengetahuan dan pendampingan dalam peningkatan kemampuan membuat AD/ART dalam rangka meningkatkan kinerja dan mekanisme kerja koperasi. Karena saat ini, banyak sekali koperasi yang mengalami gulung tikar yang salah satu diantaranya penyebabnya karena peraturan yang ada di dalam koperasi itu hanya sebuah simbolis dan minimnya pengawasan.

Berdasarkan identifikasi dan perumusan masalah tersebut serta hasil Focuss Group Discussion ( $F G D$ ) dengan anggota koperasi dan pengurus koperasi, maka tujuan kegiatan pengabdian ini adalah memberikan pendampingan pembuatan AD/ART Koperasi Wanita Swatika. Manfaat kegiatan pengabdian masyarakat ini adalah memberikan pemahaman kepada anggota koperasi dan pengurusnya untuk membuat AD/ART dalam rangka meningkatkan efektifitas dan mekanisme kerja koperasi wanita (Kopwan) Swatika dengan tetap memperhatikan ketentuan yang ada di dalam Undang-Undang No 25 Tahun 1992 tentang Perkoperasian.

\section{B. TINJAUAN PUSTAKA}

\section{Pengertian Koperasi}

Secara bahasa, koperasi berasal dari dua suku kata bahasa Inngris, yaitu 'co" dan 
'operation'. Co berarti bersama, dan dan operation berarti bekerja. Sehingga dapat diartikan co-operation (koperasi) adalah melakukan pekerjaan secara bersama (gotongroyong).

Secara istilah, pengertian koperasi adalah badan usaha yang memiliki anggota orang atau badan hukum yang didirikan dengan berlandaskan asas kekeluargaan serta demokrasi ekonomi. Koperasi merupakan produk ekonomi yang kegiatannya menjadi gerakan ekonomi kerakyatan, dan berjalan dengan prinsip gotong-royong. Beberapa definisi tentang koperasi antara lain:

a. Menurut ILO (International Labour Organization)

1. Penggabungan orang-orang berdasarkan kesukarelaan

2. Terdapat tujuan ekonomi yang ingin dicapai

3. Koperasi yang berbentuk organisasi bisnis yang diawasi dan dikendalikan secara demokratis

4. Terdapat konstribusi yang adil terhadap modal yang dibutuhkan

5. Anggota koperasi menerima resiko dan manfaat secara seimbang

b. Menurut Arifinal Chaniago

Koperasi sebagai suatu perkumpulan yang beranggotakan orang-orang atau badan hukum, yang memberikan kebebasan kepada anggota untuk masuk dan keluar dengan bekerjabersama secara kekeluargaan menjalankan usaha untuk mempertinggi kesejahteraan jasmaniah para anggotanya.

c. Menurut P.J.V. Dooren

There is no single Definition (for coopertive) which is generally accepted, but the common principle is that cooperative union is an association of member, either personal orv corporate, which voluntarily come together in pursuit of a common economic objective. Jika diartikan ke dalam bahasa Indonesia berarti "Tidak ada definisi tungal (untuk cooperative) yang umumnya diterima, tetapi prinsip yang umum menjelaskan bahwa serikat koperasi adalah sebuah asosiasi anggota, baik pribadi atau perusahaan yang telah secara sukarela datang bersama-sama dalam mengejar tujuan ekonomi umum".

d. Menurut Hatta

Koperasi adalah usaha bersama untuk memperbaiki nasib penghidupan ekonomi berdasarkan tolong-menolong. Semangat tolong menolong tersebut di dorong oleh keinginan memberi jasa kepada kawan berdasarkan "seorang buat semua dan semua buat seorang".

e. Menurut Munker

Koperasi sebagai organisasi tolong menolong yang menjalankan 'urusniaga' secara kumpulan, yang berazaskan konsep tolong menolong. Aktivitas dalam urus niaga semata- mata bertujuan ekonomi, bukan sosial seperti yang dikandung gotong royong.

f. Menurut Undang-Undang No. 25 tahun 2012 Tentang Perkoperasian

Koperasi adalah badan usaha yang beranggotakan orang seorang atau badan hukum koperasi dengan melandaskan kegiatannya berdasarkan prinsip koperasi sekaligus sebagai gerakan ekonomi rakyat yang berdasarkan atas azas kekeluargaan.

\section{Tujuan Koperasi}

Tujuan koperasi tertuang dalam UU No. 25 Tahun 1992 tentang kekoperasian, pada BAB II Pasal 3 menyatakan bahwa tujuan koperasi adalah: "Memajukan kesejahteraan angota pada khususnya dan masyarakat pada umumnya sera ikut membangun tatanan perekonomian Nasional dalam rangka mewujudkan masyarakat 
yang maju, adil dan makmur berlandaskan Pancasila dan Undang-Undang Dasar $1945^{\prime \prime}$.

\section{Fungsi dan Peran Koperasi}

Koperasi juga memiliki fungsi dan peran yang tercantum dalam Undang-undang No. 25 tahun tahun 1992 tentang Perkoperasian pasal 4 "fungsi dan peran dalam Undang-undang tersebut sebagai berikut:

a. Membangun dan mengembangkan potensi dan kemampuan ekonomi anggota dan khususnya dan masyarakat pada umumnya untuk meningkatkan kesejahteraan ekonomi dan sosialnya.

b. Berperan serta aktif dalam upaya mempertinggi kualitas kehidupan manusia dan masyarakat.

c. Memperkukuh perekonomian rakyat sebagai dasar kekuatan dan ketahanan perekonomian nasional dengan koperasi sebagai saka gurunya.

d. Berusaha mewujudkan dan mengembangkan perekonomian nasional yang merupakan usaha bersama berdasarkan atas asas kekeluargaan dan demokrasi ekonomi".

\section{Macam Koperasi}

a. Koperasi simpan pinjam. Koperasi simpan pinjam merupakan koperasi yang beranggotakan masyarakat, baik sebagai konsumen maupun sebagai produsen barang. Kegiatan koperasi ini adalah menyalenggarakan fungsi penghimpunan dana dan menyediakan pinjaman/modal untuk kepentingan anggota, baik kepada konsumen maupun produsen.

b. Koperasi konsumen. Koperasi konsumen adalah koperasi yang beranggotakan konsumen. Kegiatan dari koperasi ini adalah menyalenggarakan fungsi penyedia barang-barang kebutuhan sehari-hari untuk kepentingan anggota dan masyarakat selaku konsumen.

c. Koperasi produsen. Koperasi produsen yaitu koperasi yang beranggotakan para produsen barang dan memiliki usaha rumah tangga. Kegiatan koperasi ini adalah menyalenggarakan fungsi penyedia bahan atau sarana produksi, pemrosesan, dan pemasaran barang yang dihasilkan oleh anggota selaku produsen.

d. Koperasi pemasaran. Koperasi pemasaran yakni koperasi yang beranggotakan para pemasok barang hasil produksi. Kegiatan koperasi ini adalah menyalenggarakan fungsi pemasaran barang yang diproduksi oleh anggota.

e. Koperasi jasa. Koperasi jasa adalah koperasi yang menyalenggarakan fungsi pelayanan jasa tertentu untuk kepentingan anggota. Misalnya jasa asuransi, angkutan, serta pendidikan dan pelatihan.

Koperasi yang menyelenggarakan satu fungsi disebut koperasi tunggal usaha (single purpose cooperative), sedangkan koperasi yang menyelenggarakan lebih dari satu fungsi disebut koperasi serba usaha (multi purpose cooperative).

\section{Jenis Koperasi}

\section{1) Berdasarkan Fungsinya}

a) Koperasi pembelian/ pengadaan/ konsumsi. Koperasi pembelian/ pengadaan/ konsumsi adalah koperasi yang menyelenggarakan fungsi pembelian atau pengadaan barang dan jasa untuk memenuhi kebutuhan anggota sebagai konsumen akhir. Dikoperai in anggota berperan sebagai pemilik dan pembeli (konsumen) bagi koperasinya.

b) Koperasi penjualan/pemasaran. Koperasi penjualan/pemasaran merupakan koperasi yang menyelenggarakan fungsi distribusi barang atau jasa yang 
dihasilkan oleh anggotanya agar sampai di tangan konsumen. Di sini anggota berperan sebagai pemilik dan pemasok barang atau jasa kepada koperasinya.

c) Koperasi Produksi. Koperasi Produksi yakni koperasi yang menghasilkan barang dan jasa, dimana anggotanya bekerja sebagai pegawai koperasi. Dikoperasi jenis ini anggota berperan sebagai pemilik dan pekerja koperasi.

d) Koperasi Jasa. Koperasi Jasa yaitu koperasi yang menyelenggarakan pelayanan jasa yang dibutuhkan oleh anggota. Contohnya, simpan pinjam, asuransi, angkutan, dan lain-lain. Anggota dari koperasi ini berperan sebagai pemilik dan pengguna layanan jasa koperasi.

2) Berdasarkan tingkat dan luas daerah kerjanya

a) Koperasi primer yaitu koperasi yang minimal memiliki sebanyak 20 orang perseorangan

b) Koperasi sekunder yaitu koperasi yang terdiri dari gabungan badan-badan koperasi serta memiliki cakupan daerah kerja yang luas dibandingkan dengan koperasi primert. Koperasi ini dapat dibedakan menjadi: 1) Koperasi pusat adalah koperasi yang berangotakan minimal 5 koperasi primer; 2) Gabungan koperasi adalah koperasi yang beranggotakan minimal 3 koperasi pusat dan 3) Induk koperasi adalah koperasi yang berangotakan minimal 3 gabungan koperasi.

\section{3) Berdasarkan status anggotanya}

a) Koperasi produsen ialah koperasi yang berangotakan para produsen barang/jasa dan memiliki rumah tangga usaha.

b) Koperasi konsumen adalah koperasi yang beranggotakan para konsumen akhir atau pemakai barang/jasa yang ditawarkan para pemasok di pasar

\section{Struktur Organisasi}

Secara umum, struktur dan tatanan manajemen koperasi Indonesia dapat diruntut berdasarkan perangkat organisasi koperasi, yaitu:

1. Rapat anggota merupakan suatu wadah dari para anggota koperasi yang diorganisasikan oleh para pengurus koperasi, untuk membicarakan kepentingan organisasi maupun usaha koperasi dalam rangka mengambil keputusan dengan suara terbanyak dari para anggota yang hadir.

2. Pengurus adalah perwakilan anggota koperasi yang dipilih melalui rapat anggota yang bertugas mengelola organisasi dan usaha. Pasal 29 ayat (2) menyebutkan bahwa "pengurus merupakan pemegang kuasa rapat anggota". Kedudukan pengurus sebagai penerima mandat dari pemilik koperasi dan memiliki fungsi dan wewenang sebagai pelaksana keputusan rapat anggota sangat strategis dan menentukan maju mundurnya koperasi.

a. Pengawas adalah perangkat organisasi yang dipilih dari angota dan diberi mandat untuk melakukan pengawasan terhadap jalannya roda organisasi dan usaha koperasi

b. Pengelola adalah mereka yang diangkat dan diberhentikan oleh pengurus untuk mengembangkan usaha koperasi secara efisien dan profesional. Karena itu kedudukan pengelola adalah sebagai karyawan atau pegawai yang diberikan kuasa dan wewenang oleh pengurus.

Tanggung jawab dan Pola Manajemen dari sudut pandang organisasi

a. Rapat anggota merupakan pemegang kuasa tertinggi dalam menetapkan kebijakan umum di bidang organisasi, manajemen, dan usaha koperasi. Kebijakan yang sifatnya sangat strategis dirumuskan dan ditetapkan pada format forum rapat 
anggota. Umumnya, rapat anggota diselenggarakan setahun sekali.

b. Pengurus dipilih dan diberhentikan oleh rapat anggota. Dengan demikian, pengurus dapat dikatakan sebagai pemegang kuasa rapat angota dalam mengoperasionalkan kebijakan-kebijakan strategis yang ditetapkan rapat angota. Penguruslah yang mewujudkan arah kebijakan strategis yang menyangkut organisasi maupun usaha.

c. Pengawas mewakili anggota untuk melakukan pengawasan terhadap pelaksanaan kebijakan yang dilaksanakan oleh pengurus. Pengawas dipilih dan diberhentikan oleh rapat anggota, oleh karena itu posisi pengurus dan pengawas adalah sama.

d. Pengelola adalah tim manajemen yang diangkat dan diberhentikan oleh pengurus, untuk melaksanakan teknis operasional di bidang usaha. Hubungan pengurus dengan pengelola adalah hubungan kerja atas dasar perikatan dalam bentuk perjanjian atau kontrak.

\section{Prinsip Koperasi}

Prinsip koperasi menurut UU no. 25 tahun 1992, “yakni:

a. Keanggotaan bersifat sukarela dan terbuka,

b. Pengelolaan dilakukan secara demokrasi,

c. Pembagian SHU dilakukan secara adil sesuai dengan jasa usaha masing-masing anggota,

d. Pemberian balas jasa yang terbatas terhadap modal,

e. Kemandirian,

f. Pendidikan perkoperasian, dan

g. Kerjasama antar koperasi.

\section{Azas-Azas dan Nilai-Nilai Koperasi}

Koperasi mempunyai 2 (dua) azas, yaitu:

1. Azas kekeluargaan, artinya setiap anggota koperasi memiliki kesadaran untuk melakukan yang terbaik di setiap kegaiatan koperasi dan hal-hal yang dianggap berguna untuk semua anggota dalam koperasi.

2. Azas gotong royong, artinya setiap anggota koperasi harus memiliki toleransi, tidak egois atau individualis serta mau bekerjasama dengan lainnya.

Nilai-nilai koperasi adalah nilai kekeluargaan, mandiri, egaliterian, demokrasi, kesamaan, serta peduli dengan sesama anggota. Koperasi Indonesia berangkat dari nilainilai koletifisme yang tercermin dengan budaya gotong royong yang sejak lama ada di Indonesia.

Nilai-nilai koperasi yang tertuang di dalam Undang-Undang Nomor 25 tahun 1992 Tentang Perkoperasian yaitu pasal 5: 1) Nilai kekeluargaan; 2) Nilai menolong diri sendiri; 3) Nilai bertanggungjawab; 4) Nilai demokrasi; 5) Nilai persamaan; 5) Nilai keadilan; 6) Nilai kemandirian;

Nilai yang harus dipegang teguh anggota koperasi, diantaranya: 1) Nilai kejujuran; 2) Nilai keterbukaan; 3) Nilai tanggungjawab; 4) Nilai kepedulian terhadap sesama anggota serta orang lain

\section{Pengertian, Tujuan, Isi Anggaran Dasar}

Anggaran Dasar Koperasi adalah aturan dasar tertulis yang memuat keterangan sebagaimana dimaksud dalam pasal 8 Undang-undang Nomor 25 Tahun 1992 Tentang Perkoperasian. Anggaran dasar koperasi hanya memuat ketentuan-ketentuan pokok mengenai tata laksana organisasi, cara kerja, kegiatan usaha, kewajiban-kewajiban resiko yang harus ditanggung dan keadaan apabila terjadi sesuatu yang menyebabkan berhentinya organisasi koperasi. 
Hal-hal yang belum cukup diatur dalam ketentuan yang dimuat anggaran rumah tangga atau peraturan-peraturan khusus lainnya dari koperasi yang bersangkutan. Dalam anggaran dasar koperasi harus memperhatikan hal-hal sebagai berikut:

a. Dibuat dan disetujui oleh para anggota dalam rapat pembentukan koperasi

b. Memuat ketentuan-ketentuan yang merupakan dasar bagi tata kehidupan koperasi, dimana hal-hal yang dimuat dalam anggaran dasar tersebut harus disusun secara ringkas, singkat dan jelas agar dapat dimengerti oleh siapapun. Isi dan cara penyusunan anggaran dasar tidak boleh bertentangan dengan peraturan perundangundangan yang berlaku, khususnya Undang-Undang Nomor 25 Tahun 1992 Tentang Perkoperasian beserta peraturan pelaksanaannya.

c. Tidak bertentangan dengan ketertiban umum dan atau kesusilaan.

Tujuan anggaran dasar koperasi adalah:

a. Untuk menunjukkan adanya kejelasan tata kehidupan koperasi yang bersangkutan;

b. Untuk memudahkan tercapainhya sasaran yang dikehendaki para anggota sesuai dengan tujuan pembentukan koperasi;

c. Untuk menghindari kesimpangsiuran dalam pelaksanaan organisasi koperasi oleh siapa pun, terutama oleh alat-alat perlengkapan organisasi koperasi itu sendiri;

d. Terbentuk suatu organisasi usaha ekonomi rakyat yang berhak melaksanakan kegiatan- kegiatannya;

e. Sebagai dasar penyusunan peraturan-peraturan lainya ynag berlaku untuk dan dalam koperasi yang bersangkutan, misalnya: anggaran rumahtangga dan peraturanperaturan lainnya.

Kegunaan dari anggaran dasar koperasi adalah:

a. Menjamin ketertiban organisasi, karena dalam anggaran dasar tersebut memuat aturan tentang fungsi, tugas dan tata kerja dari alat-alat perlengkapan organisasi koperasi

b. Sebagai jaminan bagi pihak di luar koperasi, misalnya dalam rangka kerjasama usaha, permohonan kredit.

Isi Anggaran Dasar Koperasi

Pada dasarnya hal-hal yang harus dimuat dalam Anggaran Dasar Koperasi sekurang- kurangnya meliputi:

a. Nama lengkap, singkatan dan tempat kedudukan koperasi;

b. Maksud dan tujuan serta bidang usaha;

c. Ketentuan mengenai keanggotaan;

d. Ketentuan mengenai rapat anggota;

e. Ketentuan mengenai pengelolaan;

f. Ketentuan mengenai permodalan;

g. Ketentuan mengenai jangka waktu berdirinya;

h. Ketentuan mengenai pembagian Sisa Hasil Usaha;

i. Ketentuan mengenai sanksi.

Materi/isi anggaran dasar untuk setiap jenis koperasi tentunya berbeda antara satu dengan lainnya, akan tetapi agar dalam pembuatan anggaran dasar koperasi tidak menyimpang dari ketentuan yang berlaku.

\section{METODE}

Adapun khalayak sasaran strategis dalam pendampingan ini adalah pengurus koperasi dan anggota Koperasi Wanita (Kopwan) Swatika. Metode pelaksanaan kegiatan pengabdian kepada masyarakat ini adalah melalui metode: 
1. Kegiatan penyuluhan yaitu pentingnya materi tentang arti penting AD/ART dalam menunjang efektifitas dan mekanisme kinerja koperasi dan manfaat serta tujuan dari adanya AD/ART koperasi yang dilanjutkan sesi tanya jawab pengurus dan anggota koperasi.

2. Kegiatan pendampingan, dengan cara penyajian materi, dan praktek simulasi pembuatan AD/ART koperasi.

Penyampaian materi dilakukan dengan mengedepankan tekhnik dengan pendekatan pemotivasian dan disesuaikan dengan tingkat pengetahuan peserta, agar materi yang disampaikan dapat dengan mudah dicerna oleh para peserta. Pendampingan ini diberikan untuk membantu pengurus koperasi dan anggota dalam merumuskan AD/ART agar AD/ART ini tidak hanya sebagai sisi formalitas belaka. Namun, aturanaturan di dalamnya bisa diterapkan guna menunjang efektifitas dan mekanisme kinerja koperasi dalam rangka demi mensejahterakan khususnya bagi para anggota dan masyarakat pada umumnya. Adapun proses dan tahapan pelaksanaan program adalah sebagai berikut:

1. Tahap awal, tim pelaksana mengadakan persiapan dengan melakukan survey kepada para anggota koperasi dan pengurusnya. Selain itu juga melakukan wawancara dengan ketua pengurus koperasi untuk mendapatkan gambaran mengenai obyek program atau analisis situasinya. Berdasarkan hasil identifikasi masalah yang dihadapi oleh pengurus koperasi maupun anggota koperasi maka didapatlah solusi. Tim pelaksana juga mengadakan FGD dengan anggota dan pengurus koperasi untuk kesediaan mengikuti program pengabdian masyarakat. Adapun sarana prasarana pendukung untuk pelaksanaan program adalah kemudahan akses untuk melaksanakan FGD dengan para anggota koperasi dan kontribusi dan antusias yang sangat besar diberikan oleh Ketua Koperasi wanita Swatika dalam mendukung program pengabdian masyarakat ini.

2. Tahap pelaksanaan, pada tahap ini dilaksanakan kegiatan pendampingan pentingnya materi pengetahuan tentang arti penting dan kedudukan AD/ART dan perubahan AD/ART serta implikasi dari AD/ART terhadap efektifitas dan mekanisme kinerja koperasi yang dilanjutkan dengan sesi tanya jawab peserta pendampingan. Selanjutnya diadakan pendampingan dengan cara pendampingan selama 2 hari. Antusiasme para peserta ditunjukkan melalui pertanyaan yang diajukan setelah sesi penyampaian materi pendampingan oleh narasumber. Disamping itu selesainya pembuatan simulasi yang dilanjutkan ke proses tahapan selanjutnyadalam pembuatan kerangka AD/ART.

3. Tahap monitoring dan evaluasi. Monitoring dan evaluasi kegiatan pengabdian masyarakat ini dilakukan melalui kuesioner dan output dari kerangka AD/ART yang telah diselesaikan. Untuk keperluan evaluasi kuesioner tingkat pemahaman peserta dalam memahami materi yang sudah disampaikan dikelompokkan menjadi 91\%$100 \%=$ amat baik, $81 \%-90 \%=$ baik, $71 \%-80 \%+$ cukup, $61 \%-70 \%=$ kurang .

\section{HASIL DAN PEMBAHASAN}

Tujuan yang ingin dicapai dalam kegiatan pengabddian pada masyarakat dengan tema " Pendampingan Pembuatan Anggaran Dasar Anggaran Rumah Tangga Dalam Rangka Meningkatkan Mekanisme Kerja Koperasi Pada Koperasi Wanita (KOPWAN) Swatika Desa Miagan, Kecamatan Mojoagung Kabupaten Jombang adalah untuk memberikan pengetahuan akan kedudukan AD/ART yang tidak hanya sekedar sebagai formalitas dalam pendirian koperasi tetapi AD/ART juga sebagai penunjang dan 
pendukung dalam efektifitas dan mekanisme kerja koperasi dan pendampingan dalam proses pembuatan AD/ART Koperasi. Bagi anggota dan pengurus koperasi juga akan lebih memahami dan mengerti akan tugas, hak dan kewajiban masing-masing. Karena AD/ART tidak hanya sekedar formalitas belaka melainkan lebih mempertegas dan memperjelas ketentuan-ketentuan yang ada di dalam koperasi wanita (Kopwan Swatika) desa Miagan, Kecamatan Mojoagung kabupaten Jombang. Selain itu, tujuan kegiatan Program Pengabdian Masyarakat ini adalah sebagai salahsatu wujud program Perguruan Tinggi yaitu salahsatunya adalah TriDharma Perguruan Tinggi.

Berdasarkan hasil yang diperoleh dari kegiatan program pengabdian masyarakat ini, peserta pendampingan telah merasakan manfaatnya, yakni memiliki tambahan pengetahuan dan pemahaman terkait dengan kedudukan AD/ART dan peranan penting AD/ART dalam efektifitas dan meningkatkan mekanisme kinerja koperasi sekaligus khususnya bagi para anggota maupun pengurus koperasi juga akan lebih memahami tentang tugas, hak dan kewajiban dalam koperasi dan peningkatan kesejahteraan bagi masyarakat pada umumnya serta pendampingan penyuluhan memiliki kemampuan dalam pembuatan AD/ART. Hal tersebut tampak dari pengamatan tim pelaksana dan hasil diskusi pada tanya jawab peserta dengan narasumber.

Hasi tes awal (pre test) yang diberikan sebelum tim pelaksana memulai memberikan materi-materi AD/ART menunjukkan bahwa para peserta pendampingan belum memiliki pengetahuan yang cukup tentang kedudukan dan peranan AD/ART dalam koperasi. Penguasaan pembentukan AD/ART juga belum dikuasai dengan baik. Pada hari kedua pelaksanaan dengan bekal materi, para peserta telah mampu membuat baik kerangka maupun proses lebih lanjut mengenai AD/ART sesuai dengan Undangundang Nomor 25 Tahun 2012 Tentang Perkoperasian.

Lancarnya kegiatan program pengabdian masyarakat tersebut menunjukkan bahwa secara umum tujuan dari kegiatan tercapai, meskipun dilapangan terdapat beberapa kendala. Kendala tersebut adalah dalam hal penyelenggaraan kegiatan. Sebab tidak bisa ditentukan untuk hari dalam pelaksanaan kegiatan. Sedangkan pelaksanaan kegiatan pada hari kedua pelatihan sekaligus pendampingan dalam hal pembuatan AD/ART dibutuhkan waktu yang lebih lama dari waktu pelaksanaan dari tim pelaksana. Sebab, dibutuhkan waktu yang sangat cukup dan ketentuan-ketentuan yang lebih rinci dan variatif, sehingga hasil yang tertuang di dalam AD/ART lebih komplit, jelas dan terperinci.

\section{E. PENUTUP}

Berdasarkan hasil pengamatan pendampingan pembuatan AD/ART Koperasi Wanita (Kopwan) Swatika Desa Miagan Kecamatan Mojoagung, Kabupaten Jombang dapat disimpulkan bahwa Kegiatan Program Pengabdian Masyarakat dalam bentuk pendampingan pembuatan AD/ART ini dapat terlaksana dengan baik dan lancar. Hal ini tampak dari para peserta sangat antusias terutama khususnya pengurus dan anggota koperasi karena dengan pendampingan pembuatan AD/ART yang disajikan sangat bermanfaat dan informasi yang di dapatkan secara rinci serta detail dapat memberikan solusi dalam membuat AD/ART dengan tetap memperhatikan ketentuan-ketentuan yang ada di dalam Undang-Undang No 25 Tahun 1992 Tentang Perkoperasian.

Dari kegiatan yang telah dilakukan oleh penulis, disarankan kepada pihak koperasi untuk meningkatkan lagi sosialisasi dan pelatihan tentang "Koperasi" terutama koperasi- koperasi yang ada di tingkat desa. 
Sebab koperasi yang ada di desa juga mempunyai peranan dan andil yang begitu besar dalam memajukan kesejahteraan masyarakat pedesaan pada khususnya.

\section{DAFTAR PUSTAKA}

Agus, arman. 2009. Pokok-Pokok Pikiran dan Manajemen Koperasi. Jakarta: Balai Pustaka

Harsono, Y. 2006. Ideologi Koperasi Menatap Masa Depan. Yogyakarta: Pustaka Widyatam

Hendar. 2010. "Manajemen Perusahaan Koperasi”. Jakarta: Erlangga.

Pachta W, andjar, dkk. Pemahaman, Regulasi, Pendirian dan Modal Usaha. Kencana Media Group

https://id.wikipedia.org/wiki/Koperasi

http://dunsarwere.blogspot.co.id/2018/05/pengertian-koperasi-menurut-paraahli.html https://www.enjang.com/landasan-asas-dan-tujuan-koperasi/ http://www.koperasi.net/2018/06/bagaimana-memulai-sebuah-koperasi.html https://ahmadsayutinurreza.wordpress.com/2018/05/19/modal-koperasi/

Undang-Undang: Undang-Undang No. 25 Tahun 2012 Tentang Perkoperasian 